\title{
Mapping in Belgium in the 19th Century in a wider context
}

\author{
Philippe DE MAEYER ${ }^{\mathrm{a}, *}$ \\ ${ }^{a}$ Ghent University, Department of Geography, Krijgslaan 281 (S8, WE12), 9000 Gent, Belgium, philippe.demaeyer@ugent.be \\ * Corresponding author
}

Keywords: Thematic map, Topographical map, Belgium, Land ownership

\begin{abstract}
:
An important phenomenon in cartography in the 19th Century is the emergence of thematic cartography and especially distribution maps. The latter represent the spatial distribution of a particular feature in an area. Distribution maps may be qualitative such as those representing the land use or land cover, geological maps, ... or also quantitative, such as maps representing the population distribution by dots or isolines.
\end{abstract}

Even if in the 18th C. (or even earlier), some thematic maps were drawn, the real development of the thematic mapping only started in the 19th C. In cartographic literature, large attention was paid to the cholera map of Snow from 1854. It has often been cited (also in geographical information science) as an example of early spatial analysis; what he visually did is today a well-known technique and methodology of buffer analysis in GIS. But the most impressive thematic maps are the early 19th C. chronostratigraphical maps, mostly described as geological maps. This type of inventory maps important till the end of the 20th C. - are now completely substituted by digital data.

If the development of thematical maps was an answer on one hand to industrialisation and changing ideas about the concept of richness, it was on the other hand also only made possible by the development of new printing techniques.

Belgium was a forerunner in realizing geological maps. Already in the Dutch period (1815-1830) systematic field observations were executed in the southern part of Belgium. In this period a map was realized representing ore deposits ("Geologische kaart van een gedeelte der Nederlanden"), under the direction of J.E. Van Gorkum, with scientific input by professor Van Breda; the map was published in the Netherlands in 1834, after Belgian independency.

The map is also interesting from another point of view as it is representing the triangulation network the Dutch established in Belgium before 1830 in the framework of the Military Reconnaissance. They were part of a systematic mapping project under supervision of the Topographical Bureau with a section responsible for the Northern provinces and one for the Southern provinces, which realized those Military Reconnaissance maps. Captain Erzey executed a triangulation over the southern provinces. Later on, those coordinates served Vander Maelen to realize his 1:20 000 and 1: 80000 topographical mapping of Belgium.

On the one hand, the awareness that a new and a more precise surveying and cartography was needed and on the other hand that inventories of different thematic data were needed, must be seen not only in the context of industrialization but also in the change of the role of landownership in the society through the ages.

In the Middle Ages and the Renaissance, the landownership was a synonym for richness. The land-owners (abbeys, noblemen, ...) could collect taxes based on this ownership (the so-called taxation paradigm). In the 19th Century, land also became a good that could be traded. The trading land also induced a need for a stricter legal framework. In France, typically Napoleon erected not only the Cadastre Law to partition the tax collection more fairly but he also mentioned "Un bon cadastre parcellaire sera le complément de mon code en ce qui concerne la possession du sol. Il faut que les plans soient assez exacts et assez développés pour servir à fixer les limites des propriétés et empêcher les procès." (“A good land cadastre will be the complement of my code regarding the ownership of the soil. Maps must be accurate enough and developed enough to set property boundaries and prevent lawsuits") (Letter of Napoleon to his Minister of Finance Mollien). This period when land also became a negotiable good fits in a so-called legal paradigm.

The land registry reform affecting the whole French Empire cannot be seen separately from the reform Napoleon wished to set up for his topographical maps. Napoleon established a commission that had to define the cartographic system of a new topographic map covering the French Empire. Even if the ellipsoid of Delambre and the Bonne projection were retained, the map production could never be launched. The measurements of Captain Erzey in the Dutch period can be considered as the first attempt (in Belgium) to map the territory on a geodetically correct basis.

During one and a half century the negotiable aspect of land was predominant. Map making was requiring the best available geometric accuracy. The needs of map making changed fundamentally when land also became scarcer, when it became a scarce good. The increasing need for planning in the second part of the 20th C. for the sake of land scarcity finally induced - when techniques (in particular GIS) would allow it - the development of multi-purpose spatial data systems. 